\title{
Wsparcie informacyjne - oczekiwania rodziców wychowujących dziecko z niepełnosprawnością intelektualną
}

\begin{abstract}
Krajczy Sandra, Information support - the expectations of parents raising a child with intellectual disability [Wsparcie informacyjne - oczekiwania rodziców wychowujących dziecko z niepełnosprawnością intelektualną]. Interdyscyplinarne Konteksty Pedagogiki Specjalnej, nr 2, Poznań 2013. Pp. 133-149. Adam Mickiewicz University Press. ISBN 978-83-232-2594-2. ISSN 2300-391X.

The issue of social support for the family seems to be very current and significant, especially nowadays, i.e. in the time of fast changes, globalization and consumerism. Parents raising children with intellectual disability experience many kinds of difficulties which are often impossible to deal with without external support. One of the most important forms of such help is information support, which can be defined as providing information on the child's development, the methods of coping with difficulties, as well as education, treatment and therapy and the possibilities of support. The research group included 80 parents of children with moderate and severe intellectual disabilities. The mothers and fathers answered questions about people, institutions and organizations from which they expected to receive information support. They also stated their expectations about the kinds and forms of information support they needed.
\end{abstract}

KEY WORDS: family, intellectual disability, social support, information support

W ostatnim półwieczu uznano, że rodzina powinna czynnie brać udział w terapii i usprawnianiu dziecka, powinna współpracować ze specjalistami w programowaniu oddziaływań leczniczych, 
rehabilitacyjnych i wychowawczych ${ }^{1}$. To właśnie rodzina odpowiedzialna jest za to, by nie izolować dziecka od rówieśników, sąsiadów, znajomych, czyli środowiska społecznego, co sprzyja uspołecznieniu osoby i akceptacji ${ }^{2}$. Do rodziców należy ostateczna decyzja, czy dziecko zostanie objęte procesem rehabilitacji, jaki będzie jej wymiar, gdyż to oni są prawnie i moralnie odpowiedzialni za dziecko ${ }^{3}$. Wypełnianie tych zadań wymaga od matek i ojców wiedzy i umiejętności. Niezbędny jest zatem rozwój wsparcia informacyjnego tej grupy osób.

\section{Wsparcie społeczne w literaturze przedmiotu}

Problematyką wsparcia społecznego interesuje się wiele dyscyplin naukowych, tj. psychologia, pedagogika, socjologia. Stąd wynika trudność przyjęcia definicji, która jednoznacznie określałaby, czym ono jest ${ }^{4}$. Analizując definicje wsparcia takich autorów, jak H. Sęk $(2001)^{5}$, H. Sęk i R. Cieślak (2004) ${ }^{6}$, M. Winiarski (2002)7, S. Kawula

1 W. Dykcik, Problemy funkcjonowania rodziny z osobq niepetnosprawna w relacjach wewnętrznych i zewnętrznych, [w:] Z. Janiszewska-Nieścioruk (red.), Sfery życia osób z niepetnosprawnością intelektualna, Oficyna Wydawnicza Impuls, Kraków 2005, s. 40.

2 R. Borowski, Pedagogiczno-społeczne problemy osób niepetnosprawnych, Wyd. Novum, Płock 2006, s. 57-59.

${ }^{3}$ A. Maciarz, Wspomaganie rodziny w wypetnianiu podmiotowej roli w wychowaniu $i$ rehabilitacji dzieci, [w:] R. Kostecki, A. Maciarz (red.), Podmiotowa rola rodziców w rehabilitacji dzieci niepetnosprawnych, Wyd. Uczelniane WSP, Zielona Góra 1993, s. 24.

4 Z. Kawczyńska-Butrym, Niepetnosprawność - specyfika pomocy społecznej, Wyd. Śląsk, Katowice 1998, s. 87.

${ }^{5}$ H. Sęk, O wieloznacznych funkcjach wsparcia społecznego, [w:] L. Cierpiałkowska, H. Sęk (red.), Psychologia kliniczna i psychologia zdrowia, Wyd. Fundacji Humaniora, Poznań 2001, s. 14.

${ }^{6}$ H. Sęk, R. Cieślak, Wsparcie społeczne - sposoby definiowania, rodzaje i źródła wsparcia, wybrane koncepcje teoretyczne, [w:] H. Sęk, R. Cieślak (red.), Wsparcie społeczne, stres $i$ zdrowie, Wyd. Nauk. PWN, Warszawa 2004, s. 14.

${ }^{7}$ M. Winiarski, Pedagogika społeczna humanistycznie zorientowana, [w:] S. Kawula (red.), Pedagogika społeczna. Dokonania - aktualności - perspektywy, Wyd. Adam Marszałek, Toruń 2002, s. 72-73. 
(1999)8; Z. Kawczyńska-Butrym (1998)9 ${ }^{9}$ zredagowano własną definicję wsparcia jako: „pomoc udzielaną jednostce w sytuacji problemowej. Pomoc ta może być jednorazowa lub stała, jednostronna lub dwustronna i obejmować wymianę materialną, informacyjną, instrumentalną (w świadczeniu usług), emocjonalną i duchową. Może być ono udzielane przez osoby, instytucje i organizacje"10. W literaturze przedmiotu wyróżnia się wiele rodzajów wsparcia społecznego ze względu na różne kryteria, najczęściej wsparcie formalne i nieformalne. Wsparcie formalne przyjęte jest w założeniach statutowych różnych organizacji, instytucji i stowarzyszeń. Wsparcie nieformalne następuje w sposób naturalny i najczęściej dotyczy najbliższego środowiska społecznego: rodziny, przyjaciół, znajomych. Wsparcie dzieli się także na profesjonalne i nieprofesjonalne. Wsparcie profesjonalne realizowane jest przez specjalistów danej dziedziny. Wsparcie nieprofesjonalne świadczone jest przez osoby nieposiadające kierunkowych kompetencji zawodowych ${ }^{11}$. Ze względu na treść wymiany społecznej można wyróżnić różne treściowo rodzaje wsparcia. Najczęściej wyróżnia się wsparcie emocjonalne, informacyjne, instrumentalne, rzeczowe (materialne) oraz duchowe ${ }^{12}$.

Badania nad wsparciem społecznym, mimo że trwają od kilkudziesięciu lat, są cały czas na etapie weryfikowania istniejących hipotez i stawiania nowych. W związku z tym stale istnieje potrzeba prowadzenia nowych badań na ten temat ${ }^{13}$.

Aktualne jest wciąż zagadnienie informowania rodziców o niepełnosprawności dziecka. W okresie prenatalnym najważniejsza jest

8 S. Kawula, Człowiek w relacjach socjopedagogicznych. Szkice o współczesnym wychowaniu, Wyd. Akapit, Torun 1999, s. 340.

9 Z. Kawczyńska-Butrym, dz. cyt., s. 114-115.

10 S. Krajczy, Wsparcie społeczne rodziców wychowujacych dziecko z niepetnosprawnościa intelektualna w stopniu umiarkowanym i znacznym, Uniw. im. A. Mickiewicza w Poznaniu, Poznań 2012, s. 35 [niepublikowana rozprawa doktorska].

${ }_{11}$ M. Karwowska, Rodzice w trudnej sytuacji wychowania dziecka niepetnosprawnego intelektualnie, [w:] Z. Janiszewska-Nieścioruk (red.), Sfery życia osób z niepetnosprawnością intelektualna, Oficyna Wydawnicza Impuls, Kraków 2005, s. 17-18.

12 H. Sęk, R. Cieślak, dz. cyt., s. 19.

13 Tamże, s. 9. 
właściwa opieka położnicza i diagnostyka prenatalna. Badania prenatalne umożliwiają przygotowanie się na narodziny dziecka z niepełnosprawnością. Niektórzy rodzice otrzymują wsparcie już na tym etapie, większość jednak zostaje pozostawiona sama sobie ${ }^{14}$. Lekarz, personel medyczny, psycholog, pedagog współpracujący ze szpitalem powinni stanowić pierwszą grupę wsparcia dla rodziców dziecka z niepełnosprawnością intelektualną ${ }^{15}$. M.J. Hasnat oraz P. Graves wskazali, że podczas przekazywania diagnozy o niepełnosprawności dziecka lekarze powinni brać pod uwagę charakterystyczne cechy rodziców, takie jak: stan emocjonalny, inteligencja/ /wykształcenie, podejrzenia, zapotrzebowanie informacyjne, trudności językowe, różnice kulturowe, religijne, oczekiwania rodziców wobec dziecka, czynniki socjoekonomiczne oraz doświadczenia z niepełnosprawnością ${ }^{16}$. Model udzielania informacji rodzicom o możliwościach wsparcia powinien być trójwymiarowy. Pierwszy wymiar to udzielanie zwięzłych, rzeczowych, prostych informacji na temat wsparcia lokalnego. Drugi wymiar zaś to udostępnianie rodzicom informatorów, literatury. Trzeci wymiar to rozmowy z pracownikami instytucji udzielających wsparcia ${ }^{17}$. Pomoc rodzicom powinna być szybka, całodobowa i powinna opierać się na ścisłej współpracy z oddziałami położniczo-ginekologicznymi ${ }^{18}$.

14 T. Tymstra, J. Bosboom, K. Bouman, Prenatal diagnosis of Down's syndrome: Experience of women who decided to continue with the pregnancy, "International Journal of Risk \& Safety in Medicine" 2004, 16, s. 91-96.

${ }^{15}$ D. Łakomy, M. Trojańska, Wczesna pomoc dziecku głębiej upośledzonemu umystowo i jego rodzinie [w:] J. Pilecki (red.), Usprawnianie, wychowanie i nauczanie osób z głębszym upośledzeniem umysłowym, Wyd. Nauk. Uniw. Pedagogicznego w Krakowie, Kraków 2002, s. 34.

16 M.J. Hasnat, P. Graves, Disclosure of developmental disability: A study of parent satisfaction and the determinants of satisfaction, "Journal of Pediatrics and Child Health" 2000, 36, s. 29-35.

$17 \mathrm{~W}$. Mitchell, P. Sloper, Information that informs rather than alienates families with disabled children: Developing a model of good practice, "Health and Social Care in the Community" 2002, 20, s. 80.

${ }^{18}$ G. Kwaśniewska, A. Wojnarska, Pomoc rodzinie dziecka niepetnosprawnego - wybrane kierunki oddziaływań, [w:] G. Kwaśniewska, A. Wojnarska (red.), Aktualne problemy wsparcia społecznego osób niepetnosprawnych, Wyd. UMCS, Lublin 2004, s. 185. 
Na podstawie przeprowadzonych w roku 2009 badań, wśród rodziców dzieci z niepełnosprawnością, wyróżniono takie oczekiwania matek i ojców wobec pomocy psychopedagogicznej, jak: przekazanie pierwszej informacji na temat niepełnosprawności dziecka obojgu rodzicom jednocześnie; zwiększenie liczby osób pracujących $\mathrm{w}$ poradniach; rozszerzenie oferty poradni specjalistycznych; skrócenie czasu oczekiwania na poradę; zwiększenie współdziałania i współpracy wszystkich instytucji zajmujących się dzieckiem i rodziną; pomaganie całej rodzinie, a nie tylko osobie z niepełnosprawnością; dostarczanie materiałów pomocniczych do pracy z dzieckiem; spotykanie się z dzieckiem $\mathrm{w}$ domu ${ }^{19}$. W badaniach R. Burton-Smith i jego współpracowników określono najważniejsze potrzeby opiekunów osób z niepełnosprawnością. Badani najczęściej $(85 \%)$ zgłaszali potrzebę uzyskania informacji, przede wszystkim na temat usług specjalistycznych, form mieszkalnictwa dla osób z niepełnosprawnością w przyszłości, a także możliwości pomocy finansowej, świadczeń i instytucji udzielających tego typu wsparcia ${ }^{20}$. Rodzice dzieci z autyzmem i zespołem Downa, w badaniach S. Siklos, K.A. Kerns, stwierdzili, że chcieliby mieć większą wiedzę o zaburzeniu swojego dziecka oraz uzyskać informacje o dostępnych formach pomocy ${ }^{21}$.

Na podstawie wyników badań $\mathrm{W}$. Janocha wymienił postulaty osób z niepełnosprawnością i ich rodziców, mające na celu poprawienie możliwości korzystania z pomocy instytucji i organizacji. Są to m.in.: postulat ulepszenia przekazów i informacji, także przez media (66\% badanych): informacje powinny być formułowane w sposób zrozumiały dla osób z niepełnosprawnością i ich rodzin,

19 B. Wołosiuk, Pomoc rodzinie dziecka o specjalnych potrzebach edukacyjnych, [w:] M. Białas (red.), Specjalne potrzeby niepetnosprawnych, Wyd. Arson, Kraków 2011, s. 60.

${ }^{20}$ R. Burton-Smith, K.R. McVilly, M. Yazbeck, T.R. Parmenter, T. Tsutsui, Service and support needs of Australian carers supporting a family member with disability at home, „Journal of Intellectual and Developmental Disability” 2009, 34(3), s. 239-247.

${ }^{21}$ S. Siklos, K.A. Kerns, Assessing need for social support in parents of children with autism and Down syndrome, "Journal of Autism and Developmental Disorders" 2006, 36, s. 921-933. 
a także osób słabo wykształconych; zwiększenie zainteresowania instytucji charytatywnych osobami potrzebującymi pomocy, aby instytucje wychodziły naprzeciw oczekiwaniom, a nie czekały na inicjatywę osób potrzebujących (18\% badanych); poprawa kwalifikacji personelu (9\%), polepszenie kontaktów personelu instytucji charytatywnych z osobami potrzebującymi pomocy, żeby byli zorientowani merytorycznie, instruowali, jakie należy dostarczyć dokumenty, zaświadczenia itd. ${ }^{22} \mathrm{~W}$. Janocha zwrócił również uwagę, że bardzo duża potrzeba pomocy informacyjnej w zakresie możliwości uzyskania wsparcia, przede wszystkim materialnego, występuje w rodzinach z trudną sytuacją finansową, których nie stać na prywatną rehabilitację. Niezbędne są wówczas informacje o dofinansowaniach i programach wsparcia dla osób z niepełnosprawnością ${ }^{23}$.

\section{Oczekiwane wsparcie informacyjne rodziców wychowujących dziecko z niepełnosprawnością intelektualną w stopniu umiarkowanym lub znacznym - wyniki badań własnych 24}

W 2010 r. przeprowadzono badania nad wsparciem społecznym rodziców wychowujących dziecko z niepełnosprawnością intelektualną. Ich głównym celem było opisanie wsparcia społecznego rodziców wychowujących dziecko z niepełnosprawnością intelektualną $\mathrm{w}$ stopniu umiarkowanym lub znacznym. W badaniach zastosowano metodę sondażu diagnostycznego, a w ramach niej technikę wywiadu. Wywiad był wywiadem jawnym, skategoryzowanym $^{25}$. Analizie poddano wypowiedzi osiemdziesięciu rodziców

22 W. Janocha, Rodzina z osoba niepetnosprawna w społecznym systemie wsparcia, Wyd. Jedność, Kielce 2009, s. 95-99.

23 Tamże, s. 107-108.

24 S. Krajczy, dz. cyt.

25 T. Pilch, T. Bauman, Zasady badań pedagogicznych. Strategie ilościowe i jakościowe, Wyd. Akademickie Żak, Warszawa 2001, s. 80. 
wychowujących dziecko z niepełnosprawnością intelektualną w stopniu umiarkowanym lub znacznym. Dzieci, badanych rodziców, były w przedziale wiekowym od 3 do 18 lat i miały orzeczenie o niepełnosprawności lub, w przypadku dzieci powyżej 16. roku życia, orzeczenie o stopniu niepełnosprawności. W związku z tym, że dzieci do 16. roku życia mają orzeczenie o niepełnosprawności bez orzeczonego stopnia, uwzględniono stopień niepełnosprawności orzeczony do celów edukacyjnych w poradni psychologiczno-pedagogicznej. Wszystkie dzieci badanych rodziców w roku 2010 uczęszczały do placówek edukacyjnych w Poznaniu, a badani rodzice mieszkali w Poznaniu lub sąsiadujących gminach. Badaniami w większości objęto matki (78 os.) w związku z tym, że to głównie one sprawowały opiekę nad dzieckiem z niepełnosprawnością intelektualną i czuły się najbardziej kompetentne do udzielenia odpowiedzi. Z dwoma ojcami przeprowadzono wywiad samodzielnie, a z dziewięcioma wspólnie z żonami.

Do zbadania związków między zmiennymi zastosowano test niezależności $\chi^{2}$ Pearsona. Za poziom istotności uznano $p \leq 0,05$. Obliczeń dokonano z zastosowaniem programu statystycznego SPSS 14.0 for Windows ${ }^{26}$.

Analizując rodzaje wsparcia różnych autorów (H. Sęk 200127; A. Maciarz 200628; Z. Kawczyńska-Butrym 199829; A. Zamkowska 2009) ${ }^{30}$, postanowiono przyjąć następujące jego rodzaje: wsparcie materialne, wsparcie informacyjne, wsparcie instrumentalne, wsparcie emocjonalne i wsparcie duchowe. Zredagowano własną definicję

26 T.W. Pavkov, A.K. Pierce, Do biegu, gotowi - start! Wprowadzenie do SPSS dla Windows, GWP, Gdańsk 2005, s. 94-101.

${ }_{27}$ H. Sęk, dz. cyt., s. 17.

${ }^{28}$ A. Maciarz, Prozdrowotne i rehabilitacyjne znaczenie więzi emocjonalnych $i$ wsparcia społecznego rodziny z dzieckiem niepetnosprawnym, [w:] A. Maciarz, Z. Janiszewska-Nieścioruk (red.), Wspótczesne problemy pedagogiki osób z niepetnosprawnościa intelektualna, Oficyna Wydawnicza Impuls, Kraków 2006, s. 113-119.

29 Z. Kawczyńska-Butrym, dz. cyt., s. 87-90.

${ }^{30}$ A. Zamkowska, Wsparcie edukacyjne uczniów z upośledzeniem umysłowym w stopniu lekkim w różnych formach ksztatcenia na I etapie edukacji, Wyd. Politechniki Radomskiej, Radom 2009, s. 101-102. 
wsparcia informacyjnego jako: przekazywanie rodzicom dziecka z niepełnosprawnościa intelektualna informacji o rozwoju dziecka, trudnościach opiekuńczo-wychowawczych $i$ sposobach radzenia sobie z nimi, o edukacji, leczeniu i rehabilitacji, o możliwościach wsparcia dla siebie $i$ dla dziecka.

W odniesieniu do oczekiwań wsparcia informacyjnego przez matki i ojców przyjęto następujące problemy badawcze:

1. Od jakich osób, instytucji i organizacji rodzice dziecka z niepełnosprawnością intelektualną w stopniu umiarkowanym i znacznym oczekują wsparcia informacyjnego?

2. Jakie rodzaje środków pomocy w zakresie wsparcia informacyjnego pragną otrzymywać rodzice dziecka z niepełnosprawnością intelektualną w stopniu umiarkowanym lub znacznym?

Formalne ramy teorii oczekiwań opracował V.H. Vroom (1964). Oczekiwania motywują do działań służących ich realizacji. Motywacja do działania zależy jednak od dwóch podstawowych czynników: od tego, jak silnie czegoś pragniemy oraz od oczekiwanego prawdopodobieństwa zaspokojenia tego pragnienia. Zakłada się, że zachowanie określane jest przez połączenie sił tkwiących w jednostce i otoczeniu. Ponadto ludzie charakteryzują się różnym rodzajem potrzeb, pragnień i celów ${ }^{31}$. Rodzice dzieci pełnosprawnych uzyskują wiele informacji dotyczących rodzicielstwa, zmian w relacjach małżonków, wychowania i opieki nad dzieckiem z gazet, Internetu, ulotek reklamowych, a także od osób z rodziny, przyjaciół i znajomych. Do rodziców dzieci $\mathrm{z}$ niepełnosprawnością intelektualną takich porad trafia niewiele.

Na pytanie o wsparcie informacyjne niektórzy badani odpowiadali podobnie jak jedna z badanych matek: „nie ma czegoś takiego, a powinno być” (matka dziewięcioletniego chłopca $\mathrm{z}$ niepełnosprawnością intelektualną w stopniu znacznym).

Matki i ojcowie, zanim zgłoszą się o pomoc, poszukują informacji w ulotkach, gazetach, na stronach internetowych, u znajomych, sąsiadów, w programów telewizyjnych. Kiedy te wszystkie źródła informacji staną się niewystarczające, wówczas liczą na po-

31 R.W. Griffin, Podstawy zarządzania organizacjami, Wyd. Nauk. PWN, Warszawa 1998 , s. $469-470$. 
moc ze strony innych ludzi, szczególnie pracujących w instytucjach i organizacjach zajmujących się wspieraniem osób z niepełnosprawnością intelektualną. Rodzaje osób, instytucji i organizacji, od których rodzice oczekują wsparcia informacyjnego, przedstawiono w tabeli 1.

Z danych zawartych $\mathrm{w}$ tabeli wynika, że większość badanych rodziców dziecka $\mathrm{z}$ niepełnosprawnością intelektualną (67 os. 83,75\%) uważa, że państwo polskie powinno pełnić rolę informacyjną wobec nich. Konieczne jest, według matek i ojców, powołanie organu, odrębnej instytucji zajmującej się wsparciem informacyjnym rodzin $\mathrm{z}$ dzieckiem $\mathrm{z}$ niepełnosprawnością. Po otrzymaniu diagnozy rodzice chcieliby dostać informator zawierający spis oraz charakterystykę działania instytucji i organizacji udzielających

Tabela 1. Rodzaje osób, instytucji i organizacji, od których rodzice dziecka z niepełnosprawnością intelektualną oczekują wsparcia informacyjnego

\begin{tabular}{|l|c|c|}
\hline \multicolumn{1}{|c|}{$\begin{array}{c}\text { Podmioty wsparcia, od których rodzice oczekują wsparcia } \\
\text { informacyjnego }\end{array}$} & $\begin{array}{c}N \\
(N=80)\end{array}$ & {$[\%]$} \\
\hline Państwo polskie (zmiany w ustawodawstwie) & 67 & 83,75 \\
\hline Rodzice dzieci z niepełnosprawnością intelektualną & 55 & 68,75 \\
\hline Placówka szkolna dziecka & 51 & 63,75 \\
\hline Państwowy Fundusz Rehabilitacji Osób Niepełnosprawnych & 21 & 26,25 \\
\hline Pielęgniarki, lekarze pracujący w instytucjach zdrowia & 21 & 26,25 \\
\hline $\begin{array}{l}\text { Stowarzyszenia działające na rzecz osób z niepełnosprawno- } \\
\text { śią i ich rodzin }\end{array}$ & 17 & 21,25 \\
\hline Instytucje pomocy społecznej & 16 & 20,00 \\
\hline Poradnia psychologiczno-pedagogiczna & 13 & 16,25 \\
\hline Psychoterapeuci i psycholodzy & 12 & 15,00 \\
\hline Rehabilitanci i pedagodzy & 7 & 8,75 \\
\hline $\begin{array}{l}\text { Fundacje działające na rzecz osób z niepełnosprawnością } \\
\text { i ich rodzin }\end{array}$ & 4 & 5,00 \\
\hline Ośrodek wczesnej interwencji & 2 & 2,50 \\
\hline
\end{tabular}

Ź r ó d ło: na podstawie analizy wyników badań własnych 
wsparcia dzieciom z niepełnosprawnością intelektualną i ich rodzinom. Wskazane byłoby także prowadzenie rejestru osób z niepełnosprawnością i na bieżąco przesyłanie do domów aktualizowanych co roku informatorów. Matki i ojcowie już w szpitalu powinni otrzymać zestaw informacji o instytucjach wspierających, organizacjach, spis książek i stron internetowych dotyczących rozwoju, wychowania i rehabilitacji dziecka z niepełnosprawnością.

Istotną grupą, od której matki i ojcowie (55 os. - 68,75\%) oczekują wsparcia informacyjnego, są inni rodzice dzieci z niepełnosprawnością. W związku z podobieństwem doświadczeń, tymi samymi celami mogliby dzielić się zdobytymi informacjami na przykład podczas spotkań grup wsparcia, w stowarzyszeniu lub szkole. Od rodziców starszych dzieci z niepełnosprawnością oczekuje się, że podzielą się swoją wiedzą i doświadczeniem (szczególnie dotyczącym edukacji i terapii) z rodzicami dzieci młodszych.

Badani rodzice (51 os. - 63,75\%) oczekują informacji od osób pracujących w placówce edukacyjnej dziecka - przedszkolu lub szkole. Wskazane jest, by przekazywali rodzicom informacje o rozwoju dziecka, jego postępach oraz wskazówki, jak pracować terapeutycznie $\mathrm{z}$ dzieckiem $\mathrm{w}$ domu. Matki i ojcowie oczekują od nauczycieli współpracy w rozwiązywaniu problemów wychowawczych oraz stałego kontaktu telefonicznego, podczas którego będą mogli omawiać sprawy związane z dzieckiem. Przedszkole lub szkoła to instytucja, od której rodzice chcieliby uzyskać informacje o wsparciu społecznym, czyli: co im się należy z tytułu wychowania dziecka z niepełnosprawnością intelektualną, informacje o stowarzyszeniach, fundacjach, metodach rehabilitacji, a także przyszłości dziecka. Instytucje te mogłyby prowadzić cykliczne szkolenia dla rodziców. Rodzice podobne oczekiwania wsparcia informacyjnego mają wobec stowarzyszeń i fundacji.

Ważne jest, co podkreśla W. Dykcik, by matki i ojcowie otrzymywali nie tylko informacje dotyczące niepowodzeń własnego dziecka, ale także jego sukcesów i osiągnięć32.

32 W. Dykcik, Szanse i zagrożenia efektywności funkcjonowania pedagogów specjalnych zatrudnionych w szkolnictwie dla uczniów z niepetnosprawnością intelektualna, [w:] 
Z wypowiedzi badanych rodziców (21 os. - 26,25\%) wynika, że konieczne jest, by Państwowy Fundusz Rehabilitacji Osób Niepełnosprawnych (PFRON) prowadził czytelną stronę internetową ze wszystkimi informacjami o programach wsparcia, zmianach w przysługujących świadczeniach i uprawnieniach. PFRON mógłby także przesyłać informatory o wsparciu do szkól, stowarzyszeń i innych placówek oraz publikować je w Internecie. Wskazane byłoby również, aby pracownicy tej instytucji pomagali rodzicom w wypełnianiu wniosków o dofinansowania oraz udzielali im informacji o wsparciu społecznym. Rodzice podobne oczekiwania przedstawiają osobom zatrudnionym w pomocy społecznej (MOPR, PCPR i in.). Informacji o wsparciu społecznym rodzice oczekują także od lekarzy, pielęgniarek i innych osób zatrudnionych w instytucjach zdrowia. Od tych osób matki i ojcowie oczekują również konkretnych wskazówek co do postępowania z dzieckiem, opieki i pielęgnacji, informacji o przysługujących badaniach. Postulatem często powtarzanym przez badanych jest przekazywanie informacji w sposób przystępny, jednak nie ogólnikowy, dostosowany do potrzeb odbiorcy.

Od poradni psychologiczno-pedagogicznej rodzice (13 os. $16,25 \%$ ) oczekują informacji na temat edukacji (o przedszkolach, szkołach, różnicach pomiędzy szkołami integracyjnymi a specjalnymi, pomocy w wyborze szkoły) i rehabilitacji (miejsca rehabilitacji, metody pracy). Od rehabilitantów, psychologów i pedagogów pracujących z dzieckiem rodzice chcieliby dowiedzieć się o postępach dziecka, jego rozwoju oraz otrzymać wskazówki, jak pracować terapeutycznie z dzieckiem w domu. Od psychologów i psychoterapeutów rodzice oczekują porad, jak radzić sobie $\mathrm{z}$ trudnościami i stresem, a także rozmów o rodzicielstwie i małżeństwie.

Wraz z wiekiem dziecka z niepełnosprawnością intelektualną potrzeba informacji u jego rodziców ulega zmianom. W zakresie wsparcia materialnego rodzice potrzebują informacji o: instytucjach

Z. Janiszewska-Nieścioruk (red.), Człowiek z niepetnosprawnościa intelektualna. T. 1. Wybrane problemy osobowości, rodzin i edukacji osób z niepetnosprawnością intelektualną, Oficyna Wydawnicza Impuls, Kraków 2003, s. 26. 


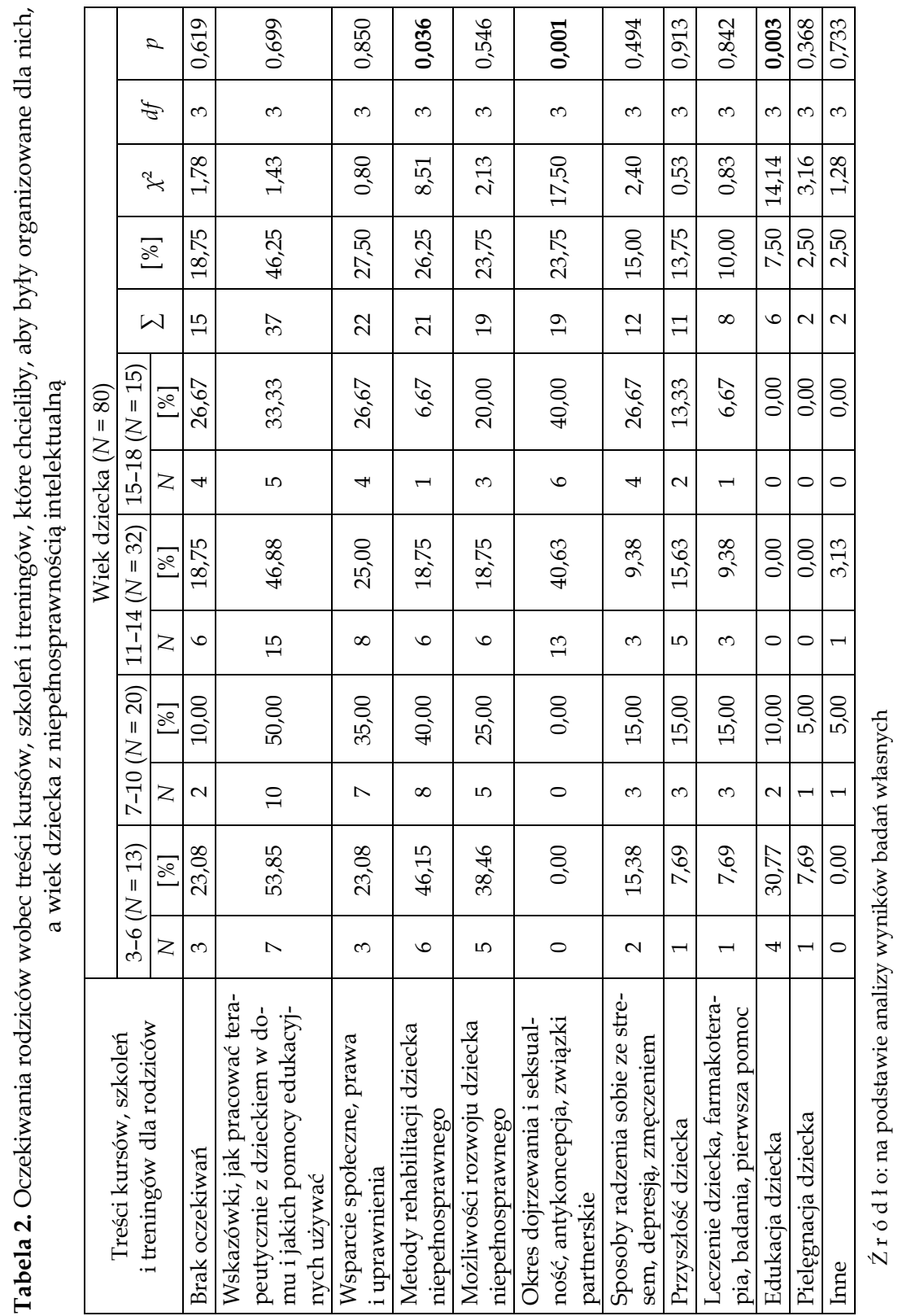


wsparcia, prawach, uprawnieniach, zmieniających się przepisach ustawodawczych, a także pomocy przy wypełnianiu wniosków o różnego rodzaju dofinansowania. Rodzicom borykającym się $\mathrm{z}$ trudnościami emocjonalnymi potrzebne są informacje o grupach wsparcia, stowarzyszeniach rodziców, możliwościach pomocy psychologicznej i psychoterapeutycznej. W zakresie wychowania, opieki, rehabilitacji i leczenia dziecka z niepełnosprawnością intelektualną rodzice powinni otrzymać informacje o edukacji, możliwościach rozwoju dziecka, ośrodkach oraz metodach rehabilitacyjnych i leczniczych.

Osoby badane zapytano również: "Jakie kursy i treningi chcieliby Państwo, żeby były organizowane dla rodziców dziecka z niepełnosprawnością intelektualną?". Brak oczekiwań w tym zakresie wyraziło 15 badanych (18,75\%). Uzyskane wyniki przedstawiono w tabeli 2.

$\mathrm{Z}$ danych zawartych $\mathrm{w}$ tabeli 2 wynika, że rodzice (37 os. $46,25 \%$ ) zauważają potrzebę uzyskania przede wszystkim wiedzy z zakresu terapii dziecka, którą mogliby kontynuować samodzielnie w domu. Matki i ojcowie oczekują konkretnych wskazówek, jak pracować nad poszczególnymi umiejętnościami i zachowaniami u dziecka. Niezbędna jest dla nich także wiedza o rodzaju i sposobach zastosowania pomocy edukacyjnych, którą mogliby wykorzystywać z dzieckiem w domu.

Wynik testu statystycznego wskazuje na istotny związek między wiekiem dziecka z niepełnosprawnością intelektualną a potrzebą jego rodziców zdobywania wiedzy o metodach rehabilitacji $\left(\chi^{2}=8,51 ; d f=3 ; p=0,036\right)$. Im dziecko jest młodsze, tym częściej jego rodzice chcą uczestniczyć w szkoleniach i kursach $z$ tej tematyki. Matki i ojcowie starszych dzieci mają doświadczenia $z$ rehabilitacji dzieci i z terapeutami. Zatem mają w tym zakresie jakąś wiedzę i dlatego mogą już nie potrzebować szkoleń z metod rehabilitacji dziecka.

Istotny statystycznie związek uzyskano również między wiekiem dziecka a oczekiwaniami rodziców organizowania szkoleń o możliwościach edukacji dziecka z niepełnosprawnością intelektu- 
alną $\left(\chi^{2}=14,14 ; d f=3 ; p=0,003\right)$. Rodzice młodszych dzieci potrzebują informacji o szkolnictwie specjalnym oraz integracyjnym, systemie edukacji dzieci z niepełnosprawnością intelektualną w Polsce. Istotny statystycznie związek uzyskano także między wiekiem dziecka a oczekiwaniami rodziców organizowania szkoleń o tematyce dojrzewania, seksualności, antykoncepcji i związków partnerskich $\left(\chi^{2}=17,50 ; d f=3 ; p=0,001\right)$. Rodzice dzieci młodszych (do 10 . roku życia) nie zastanawiają się jeszcze nad tymi zagadnieniami, natomiast już około $41 \%$ rodziców dzieci w wieku od 11 do 14 lat i około $40 \%$ dzieci w wieku od 15 do 18 lat zgłasza potrzebę wiedzy $\mathrm{z}$ tego zakresu.

Niezwykle ważna dla badanych rodziców jest także wiedza o wsparciu społecznym (uprawnieniach, możliwościach, lokalizacjach instytucji i organizacji pomocowych, procedurach uzyskiwania dofinansowań, a w szczególności wypełniania poszczególnych dokumentów i wniosków).

Dla 12 osób badanych (15,00\%) konieczne są informacji o tym, jak radzić sobie ze stresem i zmęczeniem, jakie stosować formy relaksacyjne, by przeciwdziałać wypaleniu się jako rodzic, a jednocześnie dbać o swoje zdrowie i kondycję psychiczną.

Niektórzy rodzice wyraźnie akcentują potrzebę szkolenia z farmakoterapii, leczenia dziecka, a także pierwszej pomocy. Dzieci z niepełnosprawnością cierpią bowiem na wiele sprzężonych chorób, często wymagających szybkiej interwencji, na przykład podczas ataku epilepsji. Dla matek i ojców przydatne są informacje związane z: przyszłością dziecka, formami mieszkalnictwa dla osób z niepełnosprawnością, edukacją dziecka, opieką i pielęgnacją, a także „inne” szkolenia (kursy komputerowe i z podstaw Internetu, które umożliwiłyby poszukiwanie wsparcia dla siebie i dziecka oraz pracy zarobkowej).

Reasumując powyższe rozważania, można stwierdzić, że rodzice dziecka z niepełnosprawnością intelektualną oczekują wsparcia informacyjnego przede wszystkim od instytucji państwowych, tj. ośrodków pomocy społecznej, Państwowego Funduszu Rehabilitacji Osób Niepełnosprawnych, placówek edukacyjnych oraz rehabili- 
tacyjnych. Kolejną ważną grupą osób mogących udzielić informacji są inni rodzice wychowujący dziecko z niepełnosprawnością intelektualną. Matki i ojcowie zwykle oczekują informacji o tym, jak pracować terapeutycznie $\mathrm{z}$ dzieckiem $\mathrm{w}$ domu, jakich pomocy edukacyjnych używać, jakie stosować metody rehabilitacyjne, a także wiedzy o rozwoju dziecka. Niezwykle istotna jest dla nich również wiedza z zakresu wsparcia społecznego: praw, uprawnień, jakie im przysługują, a także możliwości pomocy materialnej, emocjonalnej oraz pomocy podczas edukacji i rehabilitacji dziecka.

\section{Bibliografia}

BOROWSKI R., Pedagogiczno-społeczne problemy osób niepetnosprawnych, Wyd. Novum, Płock 2006.

Burton-SMith R., MCVIlly K.R., YAZBECK M., PARMENTER T.R., TSUTSUI T., Service and support needs of Australian carers supporting a family member with disability at home, "Journal of Intellectual and Developmental Disability" 2009, 34(3).

DYKCIK W., Problemy funkcjonowania rodziny z osoba niepetnosprawna w relacjach wewnętrznych i zewnętrznych, [w:] Z. Janiszewska-Nieścioruk (red.), Sfery życia osób z niepetnosprawnością intelektualna, Oficyna Wydawnicza Impuls, Kraków 2005.

DYKCIK W., Szanse i zagrożenia efektywności funkcjonowania pedagogów specjalnych zatrudnionych w szkolnictwie dla uczniów z niepetnosprawnościa intelektualna, [w:] Z. Janiszewska-Nieścioruk (red.), Człowiek z niepetnosprawnościa intelektualną. T. 1. Wybrane problemy osobowości, rodzin i edukacji osób z niepetnosprawnościa intelektualna, Oficyna Wydawnicza Impuls, Kraków 2003.

GRIFFIN R.W., Podstawy zarządzania organizacjami, Wyd. Nauk. PWN, Warszawa 1998.

HASNAT M.J., GRAVES P., Disclosure of developmental disability: A study of parent satisfaction and the determinants of satisfaction, "Journal of Pediatrics and Child Health" 2000, 36.

JANOCHA W., Rodzina z osoba niepetnosprawna w społecznym systemie wsparcia, Wyd. Jedność, Kielce 2009.

KARWOWSKA M., Rodzice w trudnej sytuacji wychowania dziecka niepetnosprawnego intelektualnie, [w:] Z. Janiszewska-Nieścioruk (red.), Sfery życia osób z niepetnosprawnością intelektualną, Oficyna Wydawnicza Impuls, Kraków 2005.

KAWCZYŃSKA-BUTRYM Z., Niepetnosprawność - specyfika pomocy społecznej, Wyd. Śląsk, Katowice 1998. 
KAWULA S., Człowiek w relacjach socjopedagogicznych. Szkice o wspótczesnym wychowaniu, Wyd. Akapit, Toruń 1999.

KRAJCZY S., Wsparcie społeczne rodziców wychowujacych dziecko z niepetnosprawnościa intelektualna w stopniu umiarkowanym i znacznym, Uniw. im. A. Mickiewicza w Poznaniu, Poznań 2012 [niepublikowana rozprawa doktorska].

KWAŚNIEWSKA G., WOJNARSKA A., Pomoc rodzinie dziecka niepetnosprawnego - wybrane kierunki oddziaływań, [w:] G. Kwaśniewska, A. Wojnarska (red.), Aktualne problemy wsparcia społecznego osób niepetnosprawnych, Wyd. UMCS, Lublin 2004.

ŁAKOMY D., TROJAŃSKA M., Wczesna pomoc dziecku głębiej upośledzonemu umystowo i jego rodzinie, [w:] J. Pilecki (red.), Usprawnianie, wychowanie i nauczanie osób $z$ głębszym upośledzeniem umysłowym, Wyd. Nauk. Uniw. Pedagogicznego w Krakowie, Kraków 2002.

MACIARZ A., Prozdrowotne $i$ rehabilitacyjne znaczenie więzi emocjonalnych $i$ wsparcia społecznego rodziny z dzieckiem niepetnosprawnym, [w:] A. Maciarz, Z. Janiszewska-Nieścioruk (red.), Współczesne problemy pedagogiki osób z niepetnosprawnościa intelektualna, Oficyna Wydawnicza Impuls, Kraków 2006.

MACIARZ A., Wspomaganie rodziny w wypetnianiu podmiotowej roli w wychowaniu i rehabilitacji dzieci, [w:] R. Kostecki, A. Maciarz (red.), Podmiotowa rola rodziców w rehabilitacji dzieci niepetnosprawnych, Wyd. Uczelniane WSP, Zielona Góra 1993.

MitCHELL W., SLOPER P., Information that informs rather than alienates families with disabled children: Developing a model of good practice, "Health and Social Care in the Community" 2002, 20.

PAVKov T.W., PIERCE A.K., Do biegu, gotowi - start! Wprowadzenie do SPSS dla Windows, GWP, Gdańsk 2005.

PILCH T., BAUMAN T., Zasady badań pedagogicznych. Strategie ilościowe i jakościowe, Wyd. Akademickie Żak, Warszawa 2001.

SĘK H., O wieloznacznych funkcjach wsparcia społecznego, [w:] L. Cierpiałkowska, H. Sęk (red.), Psychologia kliniczna i psychologia zdrowia, Wyd. Fundacji Humaniora, Poznań 2001.

SĘK H., CIEŚLAK R., Wsparcie społeczne - sposoby definiowania, rodzaje i źródła wsparcia, wybrane koncepcje teoretyczne, [w:] H. Sęk, R. Cieślak (red.), Wsparcie społeczne, stres $i$ zdrowie, Wyd. Nauk. PWN, Warszawa 2004.

SIKLOS S., KERNS K.A., Assessing need for social support in parents of children with autism and Down syndrome, "Journal of Autism and Developmental Disorders" 2006, 36.

TYMSTRA T., BOsBOOM J., BOUMAN K., Prenatal diagnosis of Down's syndrome: Experience of women who decided to continue with the pregnancy, "International Journal of Risk \& Safety in Medicine" 2004, 16.

VROOM V.H., Work and Motivation, John Wiley and Sons, New York 1964. 
Wsparcie informacyjne - oczekiwania rodziców wychowujących dziecko

WINIARSKI M., Pedagogika społeczna humanistycznie zorientowana, [w:] S. Kawula (red.), Pedagogika społeczna. Dokonania - aktualności - perspektywy, Wyd. Adam Marszałek, Torun 2002.

WoŁosIUK B., Pomoc rodzinie dziecka o specjalnych potrzebach edukacyjnych, [w:] M. Białas (red.), Specjalne potrzeby niepetnosprawnych, Wyd. Arson, Kraków 2011. ZAMKOWSKA A., Wsparcie edukacyjne uczniów z upośledzeniem umystowym w stopniu lekkim w różnych formach ksztatcenia na I etapie edukacji, Wyd. Politechniki Radomskiej, Radom 2009.

ZIENTEK I., Problemy niepetnosprawnych dzieci i ich rodziców, „Problemy Opiekuńczo-Wychowawcze" 1997, nr 5. 